\title{
Impact of Supplier Development on Supplier Performance: Mediating Role of Trust
}

\author{
Amer Rajput ${ }^{1}$, Saqib Gulzar ${ }^{2}$, Khurram Shafi ${ }^{3}$
}

\begin{abstract}
Value-adding functions of textile industry make the buying firms dependent on their suppliers. The buying firms utilize supplier development practices to improve supplier performance. This study utilized questionnaire survey to collect data from 345 textile firms. Regression analysis and structural equation modelling are employed to test the research framework of supplier development, supplier performance, and trust of suppliers. Indirect supplier development and direct supplier development practices affect supplier performance. Findings of the study show that supplier development practices improve supplier performance in the textile industry. Buying firms' trust is positively related to supplier performance improvement. Furthermore, it mediates across supplier development dimensions and supplier performance improvement. The study emphasizes that the large-scale manufacturing buying firms need to trust its suppliers when engaged in supplier development practices in the textile industry.. Additionally, buying firms' trust positively, significantly, and partially mediates between supplier development dimensions and supplier performance improvement in the textile industry of Pakistan.
\end{abstract}

Keywords: Indirect Supplier Development, Direct Supplier Development, Supplier Performance, Trust, Textile Industry

\section{Introduction}

Textile is a major industry for developed and developing economies to contribute for wealth generation and employment (Basheer, Siam, Awn, \& Hassan, 2019). Supply chain management (SCM) investigation is neglected for textile industry; there is invisibility of SCM in textile industry (Ali \& Habib, 2012). Although, textile industry entails a comprehensive value chain that ranges from chemical fibres to production of fabrics (Ikram, Su, Fiaz, \& Rehman, 2018).

1 Assistant Professor Department of Management Sciences COMSATS University Islamabad, Wah Campus G.T. Road, Wah Cantt, Pakistan. Email: amerrajput@comsats.edu.pk

2 Associate Professor Department of Management Sciences COMSATS University Islamabad, Wah Campus G.T. Road, Wah Cantt, Pakistan.

3 Assistant Professor Department of Management Sciences COMSATS University Islamabad, Wah Campus G.T. Road, Wah Cantt, Pakistan

\begin{tabular}{ll} 
ARTICLE HISTORY & \\
28 Sep, 2018 Submission Received & 24 Oct, 2018 First Review \\
\hline 11 Feb, 2019 Second Review & 11 Apr, 2019 Third Review \\
\hline 25 Apr, 2019 Accepted &
\end{tabular}


SCM investigations along with supplier development have been conducted for several industries of developed economies. There is lack of research for supplier development in the textile industry of a developing economy. This study investigates impact of supplier development dimensions on supplier performance through mediation of buying firms' trust particularly for large scale manufacturing (LSM) firms of the textile industry in Pakistan. SCM is investigated in various industries of Pakistan (Younus, 2019). However, it is commendable to investigate supplier development dimensions in the textile industry due to lack of research. This study compensates research gap through investigating impact of supplier development dimensions on supplier performance improvement (SPI) with mediation of buying firms' trust. Textile industry is known for its contributions to wealth generation and employment in developed and developing economies. As a matter of fact, this industry competes in the global market with its significant contributions for several years. However, research on SCM has somewhat neglected the textile industry particularly in the developing countries (Rajput \& Abu Bakar, 2011). It is acknowledged that SCM, particularly on the domain of supplier relationship management is a widely studied topic and the research in similar areas is conducted for the textile industry in the developed economies. For instance, Teng and Jaramillo (2005) develop a model to evaluate and select global suppliers for the US textile industry. This study has motivated several other studies such as one in the UK to develop interaction capability framework to support suppliers to attain positioning advantage through improved customer values (Johnsen \& Ford, 2006). Lee (2006) studies global supply chains to explore the investment decisions made by suppliers due to the buyers' needs in the textile industry. Subsequently, the importance of assessment instrument for the identification of asymmetry and symmetry of buyer-supplier relationship is suggested (Rhona E Johnsen \& David Ford, 2008). Alptekin and Alptekin (2009) suggest an approach to find the best suppliers for the buyers in the textile industry through cost, quality, and delivery time. Chen (2011) develops a structured approach for supplier evaluation and selection for the Taiwanese textile industry. Except for the study in Taiwan, there is clearly a dearth of similar studies in the developing economy such as Pakistan.

Pakistan's economy is characterized as textile-based by means of international business, foreign exchange earnings, value addition, investments, and employment (Basheer et al., 2019). Specifically, the industry accounts for $46 \%$ of entire production and $8.5 \%$ of national income to Pakistan's economy. It brings about $67 \%$ of merchandise export earnings, provides work to $38 \%$ of manufacturing workforce with half of the production of output for industrial sector, and 9\% of shares in Gross Domestic Product (GDP).

This study addresses this gap by specifically examining the impact of supplier 
development dimensions on supplier performance improvements with the mediation of buying firms' trust for large-scale manufacturing firms of the textile industry. Supplier development can result in supplier performance improvements, which lead the buying firms to undertake supplier development practices by recognizing its longterm and strategic advantage (Sánchez-Rodríguez, Hemsworth, \& Martínez-Lorente, 2005). Honda of America took up the supplier development program titled as "BP" (best practice, process, and performance) to implement the Kaizan philosophy for continuous improvement at suppliers' production, resulting in 45\% increased productivity and 67\% reduction in scrap (MacDuffie \& Helper, 1997). Since both parties (buyers and suppliers) must invest and work under mutual cooperation in order to gain the benefits from supplier development (Artz, 1999). It makes sense to render supplier performance improvements as the predictor of supplier development through mediation of buyers' trust.

Textile industry approximately contributes one-fourth of industrial value added products (Wadho \& Chaudhry, 2018). Pakistani textile industry has its significance to local economy; additionally, the industry has longest chain of production with inherent potential of supplier development practices by large manufacturers. Therefore, this study investigates the research problem that addresses the impact of supplier development practices on supplier performance improvement.

Premised on the above, these questions are considered : Do buying firms' supplier development dimensions positively relate to supplier performance improvements in the textile industry of a developing country? Is there a positive relationship between the buying firms' trust and supplier performance improvement in the textile industry of a developing country? Does buying firms' trust mediate the relationship between supplier development dimensions and supplier performance improvement in the textile industry of a developing country?

Besides narrowing the gap, this study attempts to determine whether the evidence gathered from developed countries and/or fast developing countries such as Taiwan can be generalized to other developing economies such as Pakistan. The paper proceeds to review the literature relating to the topic of interest, followed by a description of the methodology employed. The statistical findings are presented next before the results and the implications are discussed. The paper is then concluded with some possible future research directions.

\section{Literature Review}

The following part is to present literature review for supplier development dimensions, supplier performance improvement, and buying firms' trust. 


\subsection{Supplier development}

Supplier development is an attempt of the buying organization to develop its supplier for sake of performance and capability enhancement to accommodate supply requirements. Supplier development is adopted as "any effort of buying firm with a supplier to increase the performance and/or capabilities of supplier and to meet the buying firm's short and/or long term supplier needs" (Krause \& Ellram, 1997, p. 39 ). When there is no single satisfactory supplier existing in market to accomplish the buying firm's demand, the firm has to generate a new source of supply; this phenomenon is affirmed as narrow perspective of supplier development (Rogers, Purdy, Safayeni, \& Duimering, 2007). The broader perspective of supplier development encompasses long-term mutual benefits for buying firm and its supplier (Watts \& Hahn, 1993). Few studies are conducted for supplier development in the textile industry; Teng and Jaramillo (2005) presented a model to evaluate and select global suppliers for USA textile industry. UK textile industry is studied to develop interaction capability framework for smaller suppliers who interact with larger buyers. The application of this capability framework supports suppliers to attain positioning advantage through improved customer value. Global supply chains were investigated to explore investment decisions made by suppliers due to the needs of the buyers for the textile industry (Lee, 2006). The importance of assessment instrument for identification of asymmetry and symmetry for buyer-supplier relationship was suggested (Rhona E. Johnsen \& David Ford, 2008). Dearth of research is evident pertaining to supplier development in the textile industry; no study is found that is conducted exclusively to investigate supplier development dimensions in the textile industry of a developing economy. The scarcity instigated to investigate supplier development dimensions in the textile industry. Supplier development can accomplish SPI; buying firms practice supplier development by recognizing the long-term and strategic advantages (Wagner, 2011). Honda of America took up supplier development program titled as "BP" (best practice, process, and performance) to implement Kiazan philosophy for continuous improvement at suppliers' production. The productivity was increased $45 \%$ and scrap was reduced to $67 \%$. Supplier development improves operations of the suppliers with support of buying firms (Sánchez-Rodríguez et al., 2005).

Buying firm's efforts to do supplier evaluation, auditing supplier, and communication with the supplier are considered as indirect supplier development (ISD) approach (Wagner, 2006). This definition is explained further through description of some practices which are undertaken by buying firms while developing the suppliers. ISD entails practices such as the buying firms set improvement targets for the suppliers and suppliers are desired to achieve those targets. The buying firms commit with the suppliers to audit the suppliers in context of quality and performance of the 
products delivered by the suppliers. The buying firms can take on ISD by providing feedback about the performance of the suppliers. Another practice of ISD is when buying firms obligate strong formal supplier evaluation of the suppliers.

Direct supplier development (DSD) dimension of supplier development corresponds to buying firms' efforts to do human specific and capital specific investments for the suppliers to improve performance (Wagner, 2006). This is described further with description of practices related to DSD. DSD occurs when buying firms give manufacturing related advices to the suppliers. The manufacturing related advice is related to supplier firm's processes, machining processes and machine set up. Buying firm engages itself for the training of supplier firm's employees and this practice lies within the sphere of direct supplier development. DSD exists when a buying firm transfers its employees to its supplier's production plant for a specified period. DSD prevails when a buying firm gives product development related advice to its supplier about supplier's processes or project management. DSD can be taken on by a buying firm through giving technological advice to its supplier; that is related to materials and software. Buying firm engages itself with DSD through giving quality related advice to its supplier. Lastly, direct supplier development encompasses a practice when a buying firm transfers its implicit knowledge to the supplier's firm. The description of these practices related to supplier development elucidates the understanding of direct supplier development approach.

\subsection{Supplier performance improvement}

SPI is a desired outcome when buying firms practice supplier development approach. Purchasing literature presents some performance outcomes such as ability of supplier to manage its quality, delivery, lead time and control for total cost of acquisition. SPI is operated to gauge supplier development (Watts \& Hahn, 1993). Mutual benefits for buyer and supplier are generated at the platform of supplier development (Cai, Yang, \& Jun, 2011). This study contends to SPI as desired outcome of supplier development; Artz (1999) emphasizes that both parties should invest and work with cooperation to gain the benefits through supplier development. SPI can be quantified with supplier development program; improvement is associated with success of the program (P. K. Humphreys, Li, \& Chan, 2004b). Therefore, SPI is rendered as criterion for predictors of ISD and DSD through mediation of buying firms' trust. Buying firms' trust is related to particular investment contextualizing theory of social exchange in connection with supply chain partners (Kwon \& Suh, 2005). Possibly buying firms' trust and supplier development advance hand by hand; presence of trust in inter-firm relationship is evident in literature; the following discussion describes trust in inter-firm relationship. 


\subsection{Buying firms' trust}

Trust is described as nature of trust, causes of trust, trust's antecedents and trust's effects. Few definitions of trust are available in perspective of buyer-supplier relationship. Trust contributes for success of an alliance (Klein \& Rai, 2009); relationship success dependents on buyer's trust on its supplier (Nyaga, Whipple, \& Lynch, 2010). Lack of trust originates unsuccessful relationship that increases transaction cost. Theory of trust lacks its absolute understanding; however, it is studied with varying conceptions in different perspectives. This study considers buying firms' trust as mediator between supplier development and SPI. Buyer's trust is a critical factor to harvest benefits out of the inter-firm relationship (Sako, 1992). Trust is a vital cord for business relationships of buyer and supplier within a supply chain; high mutual trust leads to release more information sharing between buyer and supplier that ultimately cultivate improved capabilities and cost reduction. Trust is an important component in building and strengthening relationship between buyer and supplier (Yen, Wang, \& Horng, 2011). Trust and reliance were explored in manufacturing and construction industries of four countries UK, India, Pakistan and Poland; both were significant to build relationships with long-term perspectives (Jiang, Henneberg, \& PeterNaudé, 2011). Trust is declared as complex phenomenon that needs to be investigated further with methodological and conceptual challenges. Although, trust in inter-firm relationships is widely studied but it lacks investigation as mediator between supplier development dimensions and SPI in the textile industry. Following research questions are considered for this investigation: Do buying firms' supplier development dimensions positively relate to SPI in the textile industry? Is there positive relationship between buying firms' trust with SPI in the textile industry? Does buying firms' trust mediate between supplier development dimensions and SPI in the textile industry?

\section{Research Framework and Hypotheses}

Literature signifies initiation of supplier development process through indulgence of supplier development activities by the buying firms (Krause, 1999). Other than process activities, there exist several antecedents such as inputs' importance, top management's support, technological change and market competition (Krause, 1999). This study is not to incorporate antecedents of supplier development in the research framework. Correspondingly, this research posits buying firms' expectations for SPI when engaged in ISD and DSD; therefore, SPI is incorporated as dependent variable in the research framework.

Comparison of indirect supplier development and influence strategy suggests similarity between indirect supplier development approach and influence strategy. Information exchange, request, legalistic plea, threat, and promise are constituents 
of influence strategy (Frazier, 1984). The buying firms are dependent on influence strategy or activities of indirect supplier development approach. Indulgence into ISD approach minimizes the risk of suppliers for loss of business from buying firms. It influences suppliers to exert more efforts to improve performance. Buying firms allocate no resources or very limited resources in case of indirect supplier development approach. This approach is also prognosticated as "externalized" or "narrow" perspective for supplier development (Hahn, Watts, \& Kim, 1990; Krause, Scannell, \& Calantone, 2000; Monczka, Trent, \& Callahan, 1993; Wagner, 2010). In other words, this approach utilizes influence strategy, supplier evaluation, supplier assessment and communication. The buying firms offer incentives to the suppliers and the buying firms expect suppliers' performance improvement. This is achieved by providing feedback to the suppliers about the performance, injection of competition and promise of future business. Based on pertinent literature; when an industrial buying firms are engaged in ISD approach then the buying firms expect improvement in the suppliers' performance; therefore, the following relationship is hypothesized. $\mathrm{H}_{1}$ : ISD is positively related to SPI.

Direct supplier development approach is furthermore termed as "internalized" or "broader perspective" to develop a supplier. Buying firms dedicate relationship-specific (capital and human) resources for DSD approach to the particular suppliers conversely to indirect supplier development. The buying firms act proactively in case of DSD approach (Hahn et al., 1990; Krause et al., 2000; Monczka et al., 1993). Capital can be in shape of financing of machines and tools. Additionally, knowledge is transferred by buying firms to the suppliers in case of direct supplier development approach. Transfer of knowledge is through activities such as buying firms invite suppliers' personnel at their premises; temporary transfer of buying firms' employees to the suppliers' plants; buying firms organize training and educational programs for the suppliers and buying firms provide on-site consultation to the suppliers (Krause et al., 2000; Modi \& Mabert, 2007; Monczka et al., 1993; Wagner, 2010).

Implicit and explicit knowledge is transferred from the buying firm to the supplier through DSD approach. The buying firms are more structured and equipped with better processes and procedures due to their larger size than their suppliers. The larger buying firms are better knowledgeable than their suppliers. In case of DSD approach the knowledge is transferred that helps the supplier to become more efficient for product development, production and distribution (Wagner, 2010). Consequently, there will be improvement in the supplier performance. Transfer of knowledge occurs when direct supplier development approach is employed by a buying firm for a particular supplier (Dyer \& Hatch, 2006). Second hypothesis is established to test the relationship of DSD and SPI. $\mathrm{H}_{2}$ : DSD is positively related to SPI. 
Trust is recognized as one of critical success factors for a relationship amid two parties in supply chain such as relationship of buying firm and its supplier (J. V. Chen, Yen, Rajkumar, \& Tomochko, 2011; Krishnan, Martin, \& Noorderhaven, 2006; Sherman \& Sookdeo, 1992). Willingness of buying firm to rely upon supplier corresponds to trust (Moorman, Deshpande, \& Zaltman, 1993 p. 82). The buying firm expects that the supplier will not behave opportunistically (Nooteboom, Berger, \& Noorderhaven, 1997). Considering the explanation of trust by Morgan and Hunt (1994); it is suggested that buying firm holds reliability and integrity upon supplier. The supplier does not take needless risks that might result in unproductive effects for buying firm (Anderson \& Narus, 1990). Buying firms' risk for opportunistic behaviour is reduced when buying firms trust their suppliers (Krishnan et al., 2006; Moore, 1998). Trust eliminates the fear of buying firms about the disclosure of valuable transferred knowledge and information to the third party (Li \& Lin, 2006).

To compensate research gap this study has incorporated buying firms' trust as mediator between supplier development dimensions and SPI. Trust is associated to relationship success (Nyaga et al., 2010), immutability (Handfield \& Bechtel, 2002), and performance (Zaheer, McEvily, \& Perrone, 1998) in due course of supply chain partnership (J. V. Chen et al., 2011). Therefore, this study investigates the buying firms' trust as mediator on relationship of ISD and DSD approach with supplier performance improvement. Therefore, the following hypotheses are postulated to test empirically. $\mathrm{H}_{3}$ : Buying firms' trust is positively related to SPI. $\mathrm{H}_{4}$ : ISD has an indirect significant impact on SPI through buying firms' trust. $\mathrm{H}_{5}$ : DSD has an indirect significant impact on SPI through buying firms' trust.

Research framework as shown in Figure 1 is justified subsequently with theoretical foundations of goal-setting theory, influence strategy and transaction-cost theory (TCT). This study employs goal-setting theory at interorganizational level; the relationship of ISD with SPI is backed up with goal-setting theory. ISD in connection to SPI can be supported with theoretical foundation of influence strategy. Buying firms anticipate SPI out of relationship-specific investments despite conducting vertical integration or supplier switching (Williamson, 1985); thus, DSD approach can be supported through transaction cost theory.

\section{Methodology}

This study is a quantitative study and questionnaire survey method is employed (Zikmund, Babin, Carr, \& Griffin, 2013), all the constructs are measured through the available measures of the previous studies such as: ISD construct is measured by four items which are adopted from a previous study; the study reported satisfactory 


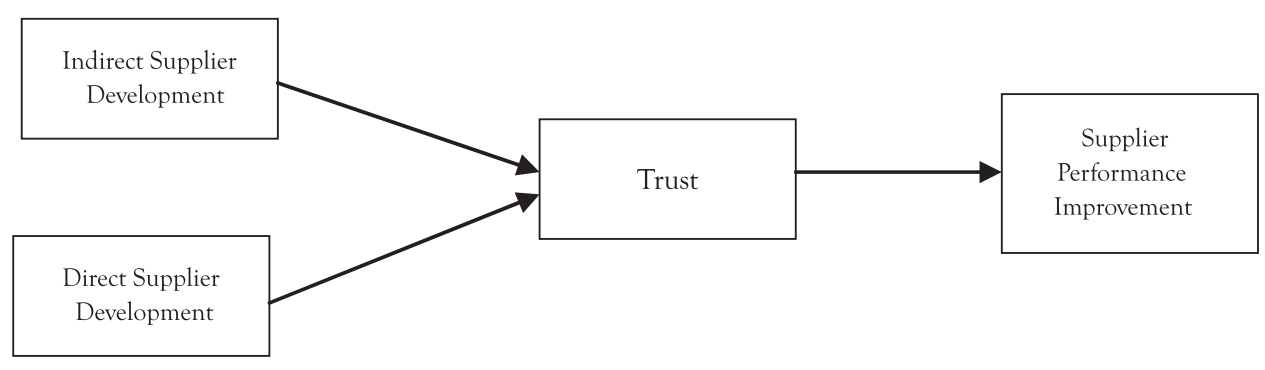

Figure 1: Research Framework

reliability level as $\alpha=0.78$ for the used scale (Wagner, 2010). Seven items are adopted from a previous study to measure DSD that presented the satisfactory reliability level $\alpha=0.83$ (Wagner, 2010). The buying firm's trust is measured by seven items; the items are adopted from the scale of a previous study that reported satisfactory reliability level $\alpha=0.94$ (Kingshott, 2006). SPI is measured by seven items that are adopted from a previous study that presented satisfactory reliability level $\alpha=0.81$ (P. $\mathrm{K}$. Humphreys et al., 2004b). Likert scale is employed to measure answers for each item. Each item was determined on 7-point scale such as $1=$ strongly disagree, 4= neutral and $7=$ strongly agree. Sample questions are given as appendix.

This study pertained firm level as unit of analysis. Knowledgeable and appropriate key informants were selected by verification of their available details; they were among top management of LSM textile firms surrounding owner, chairman, chief executive officer, president, vice president, director of purchasing function and senior purchasing manager. According to All Pakistan Textile Mills Association (APTMA), there are 991 LSM units in textile industry of Pakistan that make up population of this study. LSM units for textile industry proceeds as: 445 spinning; 140 weaving; 106 finishing; one hundred knitting and two hundred apparel/garment units (APTMA, 2010).

Sample size is considered as most important to establish adequate power of a test (Malhotra \& Grover, 1998). Sample size was calculated to acquire precise and reliable findings (Fink, 1995). Walpole (2007) suggested the formula to calculate efficient sample size; sample size of 321 was needed with confidence level 95\% and taking population into account. Target sample of $642(321 / 0.50)$ LSM textile units was estimated with assumption of $50 \%$ response rate. Convenience sampling technique is employed. Questionnaires were posted to firms which were selected from the list of APTMA. Completed 355 questionnaires were received; 345 useable responses yielded a response rate of $53.7 \%$. Survey instrument is designed largely through utilizing previous measures. 


\section{Results}

\subsection{Relationship of predictors and mediator with criterion}

Pearson correlation is conducted to identify relationship of SPI with ISD, DSD and buying firms' trust. Correlation coefficients ranged from 0.36 to 0.42 (see Table 1); ISD, DSD and buying firms' trust were significantly related to SPI in the textile industry. Moreover, correlation analysis is considered enough evidence for $\mathrm{H}_{1}, \mathrm{H}_{2}$ and $\mathrm{H}_{3}$ which describes positive relationship of SPI with ISD, DSD and buying firms' trust.

Table 1: Correlation Matrix between Predictors, Mediator and Criterion

\begin{tabular}{|c|c|c|c|c|c|c|c|}
\hline & & Mean & Std Dev & 1 & 2 & 3 & 4 \\
\hline 1. & ISD & 4.21 & 1.24 & 1 & & & \\
\hline 2. & DSD & 4.36 & 1.44 & $0.36^{*}$ & 1 & & \\
\hline 3. & Buyer's trust & 4.14 & 1.30 & $0.42^{*}$ & $0.39^{*}$ & 1 & \\
\hline 4. & SPI & 4.52 & 1.31 & $0.43^{*}$ & $0.36^{*}$ & $0.41^{*}$ & 1 \\
\hline
\end{tabular}

* Correlation is significant at the 0.01 level (2-tailed)

\subsection{Role of supplier development dimensions and buying firms' trust in SPI}

Regression analysis is combination of statistical techniques for modeling and investigating the relationship between independent and dependent variables. Testing of hypotheses with regression analysis is occurring in almost all fields including social science, economics and management. Regression analysis is reported despite the CFA. Model is said to be simple abstraction of reality that gives an approximation of complex phenomenon with utilization of regression. Linear regression analysis (LRA) was used to test $\mathrm{H}_{1}, \mathrm{H}_{2}$ and $\mathrm{H}_{3}$; it proved that ISD, DSD and buying firms' trust contributed $27 \%\left(R^{2}=0.27\right)$ variance in SPI. Standardized regression coefficient for ISD was significant for SPI $(\beta=0.27, p<0.01)$. Standardized regression coefficient of DSD was significant for SPI $(\beta=0.16, p<0.01)$. These results supported $\mathrm{H}_{1}$ and $\mathrm{H}_{2}$; hence, ISD and DSD were positively related to SPI. The standardized regression coefficient of buyer's trust was significant for SPI $(\beta=0.23, p<0.01)$; this result supported $\mathrm{H}_{3}$ that buying firms' trust was positively related to SPI (Table 2).

\subsection{Buying firms' trust as mediator between supplier development and SPI}

Baron and Kenny (1986) has suggested three equations of regressions to test mediation. Moreover, four conditions are suggested for occurrence of mediation; 
Table 2: LRA of SPI as Criterion

\begin{tabular}{|c|c|c|c|c|}
\hline Predictors & Beta & t-value & Sig. & Results \\
\hline ISD & 0.27 & 5.23 & 0.000 & $\mathrm{H}_{1}$ is supported. \\
\hline DSD & 0.16 & 3.82 & 0.001 & $\mathrm{H}_{2}$ is supported. \\
\hline Buyer's trust & 0.23 & 4.36 & 0.000 & $\mathrm{H}_{3}$ is supported. \\
\hline
\end{tabular}

$\mathrm{F}=43.47, \mathrm{p}<0.01$ and $\mathrm{R} 2=0.27$

firstly, independent variable must affect the mediator; secondly, independent variable must affect the dependent variable; thirdly, the mediator variable must affect the dependent variable in third equation; fourthly, the effect of independent variable must be decreased on dependent variable in third equation than the second equation. Findings of this research proved that buying firms' trust mediated between ISD and SPI in the textile industry. Firstly, buying firms' trust was regressed on ISD that significantly contributed to prediction of buying firms' trust with standardized regression coefficient $(\beta=0.42, p<0.01)$ and $18 \%$ of variance as shown in Table 3 . Secondly, SPI was regressed on ISD that significantly contributed to prediction of SPI with standardized regression coefficient $(\beta=0.43, p<0.01)$ and accounted for $19 \%$ variance $\left(R^{2}\right.$ change $\left.=0.19\right)$. Thirdly, SPI was regressed on both ISD and buying firms' trust; in the third equation, ISD significantly contributed for predication of SPI with standardized regression coefficient $(\beta=0.31, p<0.01)$; as well as buying firms' trust significantly contributed with standardized regression coefficient $(\beta=0.28, p<$ $0.01)$. ISD and buying firms' trust both contributed $25 \%$ variance $\left(R^{2}\right.$ change $\left.=0.25\right)$. The results meet the conditions of mediation occurrence as suggested by Baron and Kenny (1986).

Table 3: LRA for ISD as Predictor, Buyer's Trust as Mediator and SPI as Criterion

\begin{tabular}{|c|c|c|c|}
\hline Path & Model 1 & Model 2 & Model 3 \\
\hline ISD $\rightarrow$ Buyer's trust & $0.42^{*}$ & & \\
\hline ISD $\rightarrow$ SPI & & $0.43^{*}$ & \\
\hline ISD + Buyer's trust $\rightarrow$ SPI & & & $0.31,0.28^{*}$ \\
\hline F & $77.22^{*}$ & $80.46^{*}$ & $58.17^{*}$ \\
\hline Adjusted R & $0.18^{*}$ & $0.18^{*}$ & $0.24^{*}$ \\
\hline $\mathrm{R}^{2}$ change & $0.18^{*}$ & $0.19^{*}$ & $0.25^{*}$ \\
\hline
\end{tabular}

* Significant at $\mathrm{p}<0.01$ 
According to the findings, buying firms' trust mediates between DSD and SPI in the textile industry. Firstly, buying firms' trust was regressed on DSD that significantly contributed to prediction of buying firms' trust with standardized regression coefficient $(\beta=0.39, p<0.01)$ and $15 \%$ of variance as shown in Table 4. Secondly, SPI was regressed on DSD that significantly contributed to prediction of SPI with standardized regression coefficient $(\beta=0.36, p<0.01)$ and accounted for $13 \%$ variance $\left(R^{2}\right.$ change $\left.=0.13\right)$. Thirdly, SPI was regressed on both DSD and buying firms' trust; in the third equation, DSD significantly contributed for predication of SPI with standardized regression coefficient $(\beta=0.23, p<0.01)$ as well as buying firms' trust significantly contributed with standardized regression coefficient $(\beta=0.32, p$ $<0.01)$. DSD and buying firms' trust contributed $21 \%$ variance $\left(R^{2}\right.$ change $\left.=0.21\right)$. The results meet the conditions of mediation occurrence as suggested by Baron and Kenny (1986).

Table 4: LRA for DSD as Predictor, Buyer's Trust as Mediator and SPI as Criterion

\begin{tabular}{|c|c|c|c|}
\hline Path & Model 1 & Model 2 & Model 3 \\
\hline DSD $\rightarrow$ Buyer's trust & 0.39 & & \\
\hline DSD $\rightarrow$ SPI & & $0.36^{* *}$ & \\
\hline DSD + Buyer's trust $\rightarrow$ SPI & & & $0.23^{*}, 0.32^{*}$ \\
\hline F & $61.47^{*}$ & $51.04^{*}$ & $47.83^{*}$ \\
\hline Adjusted R & $0.15^{*}$ & $0.12^{*}$ & $0.21^{*}$ \\
\hline $\mathrm{R}^{2}$ change & $0.15^{*}$ & $0.13^{*}$ & $0.21^{*}$ \\
\hline
\end{tabular}

* Significant at $\mathrm{p}<0.01$

\subsection{Structural equation modeling}

Structural equation modeling (SEM) was applied to assess fit of model to the data through employment of measurement and structural model simultaneously in AMOS (See Figure 2). Commonly used indices of model parsimony were considered for model fit. Model fit indices suggested a reasonable fit with post hoc analysis to the data (Byrne, 2001). Chi-square of the model was significant (Chi-square $=504.65 ; \mathrm{df}=$ $263 ; p<0.01) . \mathrm{CMIN} / \mathrm{DF}=1.91$ that was less than the acceptable value $\leq 2$. RMSEA $=0.052$ that was less than the reasonable fit value $<0.06 . \mathrm{IFI}=0.942, \mathrm{TLI}=0.933$, and $\mathrm{CFI}=0.941$ were all greater than the acceptable value $\geq 0.90$.

\section{Discussion}

The findings of this study are in line with the previous researches; as results support that indirect supplier development is significantly and positively related to supplier 


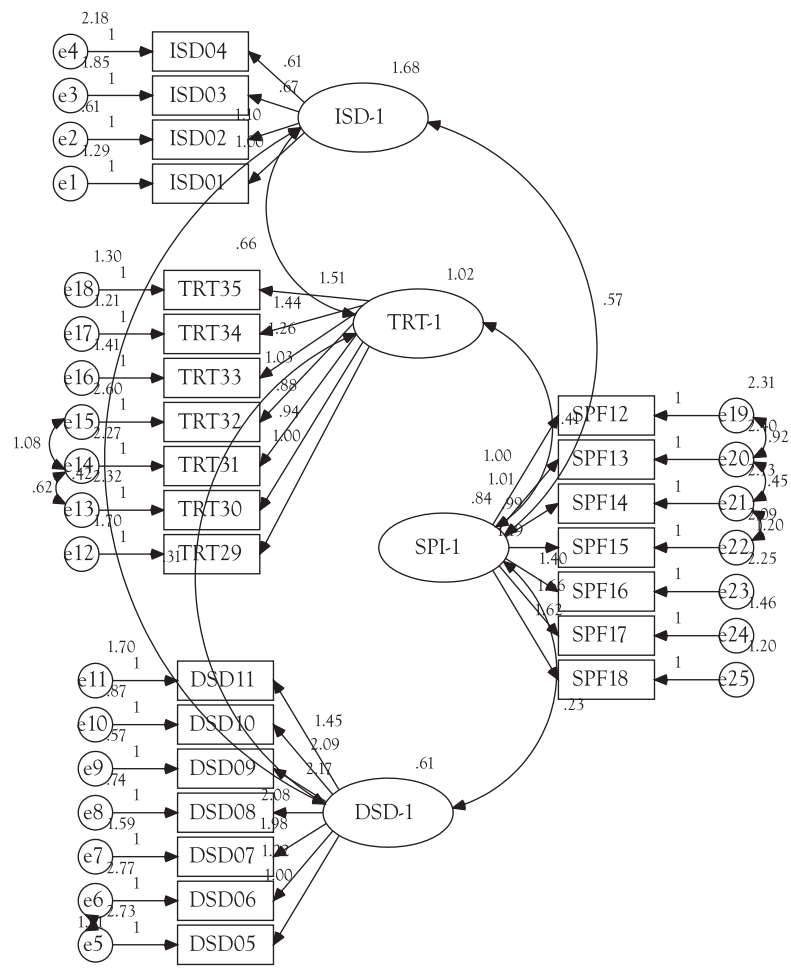

Figure 2: Results of Structural Model

performance improvement. This study has found support for goal-setting theory at organization level as supplier performance improvement has positive relationship with ISD; in other words it can be said that the buying firms in the textile industry set the goals for their suppliers that brought forth the improvements (Latham, 2004; Linderman, Schroeder, \& Choo, 2006; O Leary-Kelly, Martocchio, \& Frink, 1994). Findings of this study validate the goal-setting theory (Golembiewski, 2000; E. Locke, 2009; E. A. Locke \& Latham, 1990). This study corresponds that the utilization of ISD is very fruitful for the buying firms as well as for the suppliers in the textile industry of Pakistan.

The buying firms of textile industry are practicing DSD in conjunction to ISD. The knowledge is being transferred by the buying firms to their suppliers in the textile industry through DSD. DSD is significantly and positively related to SPI in the textile industry; the effect of DSD on SPI was confirmed through this study as suggested by knowledge-based view of the firm (Grant, 1996; Kogut \& Zander, 1992; Modi \& Mabert, 2007). Buying firms of the textile industry have invested in their suppliers to reap the benefits of DSD that supports to transaction-cost theory (Williamson, 1985). The findings are in line with transaction cost theory; this study found that DSD was 
positively and significantly related to SPI in the textile industry; therefore, transfer of knowledge, human, and capital investments were being performed by the buying firms of the textile industry. These activities of DSD are helping the buying firms and their suppliers; the finding about the effect of DSD on SPI commemorates with the results of previous studies (P. Humphreys, Cadden, Wen-Li, \& McHugh, 2011; P. K. Humphreys, Li, \& Chan, 2004a).

Moreover, this study considered buying firms' trust as a mediator between the relationship of ISD, DSD, and SPI. Buying firms' trust was positively related to SPI. This implies that trust of buying firms contributes to the performance of the suppliers. Buying firms' trust as a significant predictor of SPI commemorates with previous pertinent studies (J. V. Chen et al., 2011; Hosmer, 1995; Liu, 2012; Nyaga et al., 2010; Zaheer et al., 1998). Additionally, this study compensated research gap through proving findings about buying firms' trust as mediator between supplier development and SPI. Support was found that buying firms' trust mediates between supplier development and SPI.

SPI is positively and significantly related to the dimensions of supplier development. Textile industrial buying firms catered very limited resources to develop their suppliers withDSD. ISD dimension uses influence strategy (Frazier, 1984; Frazier $\&$ Rody, 1991) to affect SPI; influence strategy is supported through the findings. Commemorated with previous studies (Wagner, 2010); buying firms expected SPI with incorporation of ISD dimension was found positive and significant for LSM firms in the textile industry of a developing economy.

Goal-setting theory at organization level is justified as SPI has positive relationship with ISD; in other words it can be said that the buying firms in the textile industry set the goals for their suppliers that brought forth SPI (Latham, 2004). Findings validate goal-setting theory. These findings commemorate with previous studies (P. K. Humphreys et al., 2004b); the findings are in line with transaction cost theory. DSD was positively and significantly related to SPI; therefore, human and capital investments were being performed by LSM buying firms in the textile industry. These activities are helping textile buying firms and their suppliers for mutual benefits. Buying firms' trust is positively and significantly related to SPI; moreover, buying firms' trust positively, significantly and partially mediates between supplier development dimensions and SPI.

The results prove that buying firms' trust is a critical success factor for successful relationship of buying firms with their suppliers in perspective of supplier development. Previous studies investigated the relationship of trust with supplier development; however, this study specifically investigated buying firms' trust as mediator between supplier development dimensions and SPI. Buying firms' trust is a significant predictor 
of SPI that commemorates with previous studies (Liu, 2012).

\section{Conclusions and Policy Implications}

This study stands as initial investigation in the textile industry of Pakistan for supplier development dimensions. It has investigated SPI due to employment of supplier development dimensions by LSM textile firms. The study has investigated nature and strength of relationship between supplier development dimensions and SPI. SPI is positively and significantly related to dimensions of supplier development. Textile industrial buying firms catered very limited resources to develop their suppliers withDSD. This study has found support for goal-setting theory at organization level as the buying firms in textile industry set the goals for their suppliers. Low level human and capital investments are being performed by LSM buying firms in the textile industry of Pakistan. These activities are helping textile industrial buyers and their suppliers for mutual benefit of performance improvement. Trust is a critical success factor for successful relationship of buying firms with their suppliers in perspective of supplier development. Additionally, important knowledge contribution is attained through filling of research gap compensated through proving findings for buying firms' trust as mediator between supplier development dimensions and SPI. Support was found that buying firms' trust partially and significantly mediated between ISD and SPI; as well as, buying firms' trust partially and significantly mediated between DSD and SPI. Supplier development practices can be put forward based on trust as proven by the results. Importance and utilization of supplier development dimensions are vivid in LSM firms of textile industry. Merely utilization of ISD and DSD is not enough for SPI; buying firms' trust is an essential mediator that needs due consideration to enhance suppliers' performance improvement. It is argued that to take full advantages of ISD and DSD to improve supplier performance, the LSM buying firms need to trust their suppliers. Future research is recommended to investigate this research framework through adding the construct of commitment for the buying firms and their suppliers.

\section{References}

Ali, M., \& Habib, D. M. (2012). Supply chain management of textile industry: A case study on Bangladesh. International Journal of Supply Chain Management, 1(2), 35-40.

Alptekin, S. E., \& Alptekin, G. I. (2009). Product improvement by selecting appropriate suppliers: A case study. Paper presented at the Information, Process, and Knowledge Management,IEEE Conference 129-134.

Anderson, J. C., \& Narus, J. A. (1990). A model of distributor firm and manufacturer firm working partnerships. Journal of Marketing, 54(1), 42-58. 
APTMA. (2010). Pakistan Textile Statistics. Retrieved from www.aptma.org.pk

Artz, K. W. (1999). Buyer-supplier performance: the role of asset specificity, reciprocal investments and relational exchange. British Journal of Management, 10(2), 113-126.

Baron, R. M., \& Kenny, D. A. (1986). The moderator-mediator variable distinction in social psychological research: Conceptual, strategic, and statistical considerations. Journal of Personality and Social Psychology, 51(6), 1173-1182.

Basheer, M., Siam, M., Awn, A., \& Hassan, S. (2019). Exploring the role of TQM and supply chain practices for firm supply performance in the presence of information technology capabilities and supply chain technology adoption: A case of textile firms in Pakistan. Uncertain Supply Chain Management, 7(2), 275-288.

Byrne, B. M. (2001). Structural Equation Modeling With Amos: Basic Concepts, Applications, and Programming: Lawrence Erlbaum Associates.

Cai, S., Yang, Z., \& Jun, M. (2011). Cooperative norms, structural mechanisms, and supplier performance: Empirical evidence from Chinese manufacturers. Journal of Purchasing and Supply Management, 17(1), 1-10. doi:DOI: $10.1016 /$ j.pursup.2009.12.006

Chen, J. V., Yen, D. C., Rajkumar, T. M., \& Tomochko, N. A. (2011). The antecedent factors on trust and commitment in supply chain relationships. Computer Standards $\mathcal{E}$ Interfaces, 33(3), 262-270. doi:DOI: 10.1016/j.csi.2010.05.003

Chen, Y.-J. (2011). Structured methodology for supplier selection and evaluation in a supply chain. Information Sciences, 181(9), 1651-1670.

Dyer, J. H., \& Hatch, N. W. (2006). Relation-specific capabilities and barriers to knowledge transfers: Creating advantage through network relationships. Strategic Management Journal, 27(8), 701-719.

Fink, A. (1995). How to Analyze Survey Data: SAGE Publications.

Frazier, G. L. (1984). Interfirm influence strategies and their application within distribution channels. Journal of Marketing, 48(3), 43-55.

Frazier, G. L., \& Rody, R. C. (1991). The use of influence strategies in interfirm relationships in industrial product channels. Journal of Marketing, 55(1), 52-69.

Gary Teng, S., \& Jaramillo, H. (2005). A model for evaluation and selection of suppliers in global textile and apparel supply chains. International Journal of Physical Distribution $\mathscr{E}$ Logistics Management, 35(7), 503-523.

Golembiewski, R. T. (2000). Handbook of organizational behavior, Second Edition, Revised and Expanded: Taylor \& Francis.

Grant, R. M. (1996). Toward a knowledge-based theory of the firm. Strategic Management Journal, 17(2), 109-122. 
Hahn, C. K., Watts, C. A., \& Kim, K. Y. (1990). The supplier development program: A conceptual model. Journal of Purchasing and Materials Management, 26(2), 2-7.

Handfield, R. B., \& Bechtel, C. (2002). The role of trust and relationship structure in improving supply chain responsiveness. Industrial Marketing Management, 31(4), 367-382. doi:Doi: 10.1016/ s0019-8501(01)00169-9

Hosmer, L. T. (1995). Trust: The connecting link between organizational theory and philosophical ethics. Academy of Management Review, 20(2), 379-403.

Humphreys, P., Cadden, T., Wen-Li, L., \& McHugh, M. (2011). An investigation into supplier development activities and their influence on performance in the Chinese electronics industry. Production Planning E Control, 22(2), 137-156. doi:10.1080/09537281003733762

Humphreys, P. K., Li, W. L., \& Chan, L. Y. (2004a). The impact of supplier development on buyer-supplier performance. Omega The International Journal of Management Science, 32(2), 131-143. doi:DOI: 10.1016/j.omega.2003.09.016

Humphreys, P. K., Li, W. L., \& Chan, L. Y. (2004b). The impact of supplier development on buyer-supplier performance. Omega, 32(2), 131-143. doi:DOI: 10.1016/j.omega.2003.09.016

Ikram, A., Su, Q., Fiaz, M., \& Rehman, R. U. (2018). Cluster Strategy and Supply Chain Management: The Road to Competitiveness for Emerging Economies. Benchmarking: An International Journal, 25(5), 1302-1318. doi:https://doi.org/10.1108/BIJ-06-2015-0059

Jiang, Z., Henneberg, S. C., \& PeterNaudé. (2011). The importance of trust vis-à-vis reliance in business relationships: some international findings. International Marketing Review, 28(4), 318-339.

Johnsen, R. E., \& Ford, D. (2006). Interaction capability development of smaller suppliers in relationships with larger customers. Industrial Marketing Management, 35(8), 1002-1015.

Johnsen, R. E., \& Ford, D. (2008). Exploring the concept of asymmetry: A typology for analysing customer-supplier relationships. Industrial Marketing Management, 37(4), 471-483. doi:DOI: 10.1016/j. indmarman.2007.05.004

Johnsen, R. E., \& Ford, D. (2008). Exploring the concept of asymmetry: A typology for analysing customer-supplier relationships. Industrial Marketing Management, 37(4), 471-483.

Kingshott, R. P. J. (2006). The impact of psychological contracts upon trust and commitment within supplier-buyer relationships: A social exchange view. Industrial Marketing Management, 35(6), 724 739. doi:DOI: $10.1016 /$ j.indmarman.2005.06.006

Klein, R., \& Rai, A. (2009). Interfirm strategic information flows in logistics supply chain relationships. MIS Q., 33(4), 735-762.

Kogut, B., \& Zander, U. (1992). Knowledge of the firm, combinative capabilities, and the replication of technology. Organization Science, 3(3), 383-397. 
Krause, D. R. (1999). The antecedents of buying firms' efforts to improve suppliers. Journal of Operations Management, 17(2), 205-224. doi:Doi: 10.1016/s0272-6963(98)00038-2

Krause, D. R., \& Ellram, L. M. (1997). Success factors in supplier development. International Journal of Physical Distribution $\mathcal{E}$ Logistics Management 27(1), 39-52.

Krause, D. R., Scannell, T. V., \& Calantone, R. J. (2000). A structural analysis of the effectiveness of buying firms' strategies to improve supplier performance. Decision Sciences, 31(1), 33-55.

Krishnan, R., Martin, X., \& Noorderhaven, N. G. (2006). When does trust matter to alliance performance? Academy of Management Journal, 49(5), 894-917.

Kwon, I.-W. G., \& Suh, T. (2005). Trust, commitment and relationships in supply chain management: a path analysis. Supply Chain Management: An International Journal, 10(1), 26-33.

Latham, G. P. (2004). Motivating employee performance through goal-setting. In E. A. Locke (Ed.), Handbook of Principles of Organizational Behavior (2 ed.). Oxford: Blackwell Publishing Ltd.

Lee, Y.-T. (2006). Buyer influence and supplier development in buyer-driven global supply chains. (D.B.A. 3218550), Boston University, United States - Massachusetts. Retrieved from http://proquest.umi.

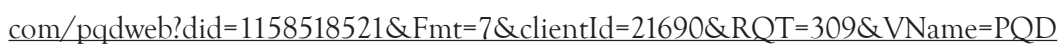

Li, S., \& Lin, B. (2006). Accessing information sharing and information quality in supply chain management. Decision Support Systems, 42(3), 1641-1656. doi:DOI: 10.1016/j.dss.2006.02.011

Linderman, K., Schroeder, R. G., \& Choo, A. S. (2006). Six Sigma: The role of goals in improvement teams. Journal of Operations Management, 24(6), 779-790. doi:DOI: 10.1016/j.jom.2005.08.005

Liu, C. L. E. (2012). An investigation of relationship learning in cross-border buyer-supplier relationships: The role of trust. International Business Review, 21(3), 311-327. doi:10.1016/j.ibusrev.2011.05.005

Locke, E. (2009). Handbook of Principles of Organizational Behavior: Indispensable Knowledge for Evidence-Based Management: John Wiley \& Sons.

Locke, E. A., \& Latham, G. P. (1990). A theory of goal setting $\mathcal{E}$ task performance: Prentice Hall.

MacDuffie, J. P., \& Helper, S. (1997). Creating lean suppliers: diffusing lean production through the supply chain. California Management Review, 39(4), 118-151.

Malhotra, M. K., \& Grover, V. (1998). An assessment of survey research in POM: from constructs to theory. Journal of Operations Management, 16(4), 407-425. doi:10.1016/s0272-6963(98)00021-7

Modi, S. B., \& Mabert, V. A. (2007). Supplier development: Improving supplier performance through knowledge transfer. Journal of Operations Management, 25(1), 42-64. doi:DOI: 10.1016/j. jom.2006.02.001

Monczka, R. M., Trent, R. J., \& Callahan, T. J. (1993). Supply base strategies to maximize supplier performance. International Journal of Physical Distribution $\mathcal{E}$ Logistics Management, 23(4), 42 - 54. 
Moore, K. R. (1998). Trust and relationship commitment in logistics alliances: A buyer perspective. Journal of Supply Chain Management, 34(1), 24-37. doi:10.1111/j.1745-493X.1998.tb00039.x

Moorman, C., Deshpande, R., \& Zaltman, G. (1993). Factors affecting trust in market research relationships. Journal of Marketing, 57(1), 81-101.

Morgan, R. M., \& Hunt, S. D. (1994). The commitment-trust theory of relationship marketing. Journal of Marketing, 58(3), 20-38.

Nooteboom, B., Berger, H., \& Noorderhaven, N. G. (1997). Effects of trust and governance on relational risk. Academy of Management Journal, 40(2), 308-338.

Nyaga, G. N., Whipple, J. M., \& Lynch, D. F. (2010). Examining supply chain relationships: Do buyer and supplier perspectives on collaborative relationships differ? Journal of Operations Management, 28(2), 101-114. doi:DOI: 10.1016/j.jom.2009.07.005

O Leary-Kelly, A. M., Martocchio, J. J., \& Frink, D. D. (1994). A review of the influence of group goals on group performance. Academy of Management Journal, 37(5), 1285-1301.

Rajput, A., \& Abu Bakar, A. H. (2011). A Reprise Of Supply Chain Management In Consanguinity To The Industry Of Textile. Management $\mathcal{E}$ Marketing, 9(2), 225-236.

Rogers, K. W., Purdy, L., Safayeni, F., \& Duimering, P. R. (2007). A supplier development program: Rational process or institutional image construction? Journal of Operations Management, 25(2), 556 572. doi:DOI: 10.1016/j.jom.2006.05.009

Sako, M. (1992). Price, Quality and Trust: Interfirm Relations in Britain and Japan: Cambridge University Press.

Sánchez-Rodríguez, C., Hemsworth, D., \& Martínez-Lorente, Á. R. (2005). The effect of supplier development initiatives on purchasing performance: a structural model. Supply Chain Management: An International Journal, 10(4), 289-301.

Sherman, S., \& Sookdeo, R. (1992). Are strategic alliances working? Fortune, 126(6), 77-78.

Teng, S. G., \& Jaramillo, H. (2005). A model for evaluation and selection of suppliers in global textile and apparel supply chains. International Journal of Physical Distribution $\mathcal{E}$ Logistics Management, 35(7), 503-523.

Wadho, W., \& Chaudhry, A. (2018). Innovation and firm performance in developing countries: The case of Pakistani textile and apparel manufacturers. Research Policy, 47(7), 1283-1294.

Wagner, S. M. (2006). Supplier Development Practices: An Exploratory Study. European Journal of Marketing, 40(5/6), 554-571.

Wagner, S. M. (2010). Indirect and direct supplier development: Performance implications of individual and combined effects. IEEE Transactions on Engineering Management, 57(4), 536-546.

Wagner, S. M. (2011). Supplier development and the relationship life-cycle. International Journal of Pro- 
duction Economics, 129(2), 277-283. doi:DOI: 10.1016/j.ijpe.2010.10.020

Walploe. (2007). Probability $\mathcal{E}$ Statistics For Engineers $\mathcal{E}$ Scientists, 8/E: Pearson Education.

Watts, C. A., \& Hahn, C. K. (1993). Supplier development programs: An empirical analysis. International Journal of Purchasing and Materials Management, 29(2), 10-17.

Williamson, O. E. (1985). The Economic Institutions of Capitalism. New York: Free Press.

Yen, Y.-X., Wang, E. S.-T., \& Horng, D.-J. (2011). Suppliers' willingness of customization, effective communication, and trust: a study of switching cost antecedents. Journal of Business $\mathcal{E}$ Industrial Marketing, 26(4), 250-259.

Yoo-Taek, L. (2006). Buyer influence and supplier development in buyer-driven global supply chains. (Doctoral dissertation), Boston University, Massachusetts, United States (3218550)

Younus, T. (2019). Analysing the impact of supply chain practice and preceding cooperative behaviour on supply chain performance efficiency: A study on Pakistan food industry. Social Science and Humanities Journal, 3(4), 1020-1038.

Zaheer, A., McEvily, B., \& Perrone, V. (1998). Does trust matter? Exploring the effects of interorganizational and interpersonal trust on performance. Organization Science, 9(2), 141-159.

Zikmund, W. G., Babin, B. J., Carr, J. C., \& Griffin, M. (2013). Business research methods: Cengage Learning. 


\section{Appendix}

\section{Questionnaire items}

\begin{tabular}{|c|}
\hline Construct of indirect supplier development (ISD) \\
\hline Our firm has taken supplier development with supplier $\mathrm{X}$ through setting improvemen \\
\hline Our firm has taken supplier development with supplier $\mathrm{X}$ through auditing supplier $\mathrm{X}$ \\
\hline $\begin{array}{l}\text { Our firm has taken supplier development with supplier } \mathrm{X} \text { through providing feedback about perfor- } \\
\text { mance. }\end{array}$ \\
\hline $\begin{array}{l}\text { Our firm has taken supplier development with supplier X through strong formal supplier evalua- } \\
\text { tion. }\end{array}$ \\
\hline Construct of direct supplier development (DSD) \\
\hline $\begin{array}{l}\text { Our firm has undertaken supplier development with supplier X through giving manufacturing-re- } \\
\text { lated advice (e.g., processes, machining process, machine setup) }\end{array}$ \\
\hline $\begin{array}{l}\text { Our firm has undertaken supplier development with supplier X through training of employees } \\
\text { from supplier X. }\end{array}$ \\
\hline $\begin{array}{l}\text { Our firm has undertaken supplier development with supplier X through transfer of employees to } \\
\text { supplier X. }\end{array}$ \\
\hline $\begin{array}{l}\text { Our firm has undertaken supplier development with supplier X through giving product-develop- } \\
\text { ment-related advice (e.g., processes, project management). }\end{array}$ \\
\hline $\begin{array}{l}\text { Our firm has undertaken supplier development with supplier X through giving technological } \\
\text { advice (e.g., materials, software). }\end{array}$ \\
\hline $\begin{array}{l}\text { Our firm has undertaken supplier development with supplier X through giving quality- related } \\
\text { advice (e.g., use of inspection equipment, quality assurance procedures). }\end{array}$ \\
\hline $\begin{array}{l}\text { Our firm has undertaken supplier development with supplier X through the transfer of implicit } \\
\text { knowledge. }\end{array}$ \\
\hline Construct of supplier performance improvement (SPI) \\
\hline $\begin{array}{l}\text { There is improvement in percentage of orders meeting design specification through supplier devel- } \\
\text { opment }\end{array}$ \\
\hline There are improvements in orders meeting quality requirements due to supplier development \\
\hline Percentage of on-time deliveries are improved through supplier development \\
\hline Improvement in cost of purchased parts occurred due to supplier development \\
\hline $\begin{array}{l}\text { Improvement in average investment in purchased parts inventory occurred through supplier devel- } \\
\text { opment }\end{array}$ \\
\hline Improvement in lead time for special/rush orders occurred as of supplier development \\
\hline $\begin{array}{l}\text { Improvement in time required for supplier to take a new item from development into production } \\
\qquad \text { occurred through supplier development }\end{array}$ \\
\hline
\end{tabular}




\begin{tabular}{|c|}
\hline Construct of trust (TRT) \\
\hline In our relationship, our major supplier cannot be trusted ${ }^{*}$ \\
\hline In our relationship, our major supplier is perfectly honest and truthful. \\
\hline In our relationship, our major supplier can be trusted completely. \\
\hline In our relationship, our major supplier can be counted to do what is right. \\
\hline In our relationship, our major supplier is always faithful. \\
\hline In our relationship, our major supplier is someone that I have great confidence in. \\
\hline In our relationship, our major supplier has high integrity. \\
\hline
\end{tabular}

